\title{
Empirical Research on Spillover Effect among Stock, Money and Foreign Exchange Market of China
}

\author{
Yunlong Yu, Dong Liao \\ School of Economics, Jinan University, Guangzhou, China \\ Email:1193729001@qq.com,2201480576@qq.com
}

How to cite this paper: Yu, Y.L. and Liao, D. (2017) Empirical Research on Spillover Effect among Stock, Money and Foreign Exchange Market of China. Modern Econo$m y$, 8, 655-666.

https://doi.org/10.4236/me.2017.85047

Received: March 27, 2017

Accepted: May 9, 2017

Published: May 12, 2017

Copyright ( 2017 by authors and Scientific Research Publishing Inc. This work is licensed under the Creative Commons Attribution International License (CC BY 4.0).

http://creativecommons.org/licenses/by/4.0/

\section{(c) (i) Open Access}

\begin{abstract}
With the openness and marketization of China's financial market accelerating, the linkage between various financial markets is increasingly significant. By utilizing VAR model and asymmetric GARCH $(1,1)$-BEKK model, this paper analyzes the price spillover effect and the volatility spillover effect among stocks returns, exchange rate of returns and money rate. The results show that 1) between currency market and stock market there is only unidirectional mean spillover effect from currency market to stock market; 2) however, there exists asymmetrical bidirectional mean spillover effect both between stock market and money market and currency market and money market, which exhibits time-varying variance and volatility persistence; 3 ) there exists bidirectional volatility spillover effect between currency market and money market, however there is only unidirectional volatility spillover effect from stock market to money market, which is demonstrated from money market to currency market.
\end{abstract}

\section{Keywords}

Stock Market, Currency Market, Money Market, GARCH-BEKK Model, Spillover Effect

\section{Introduction}

With the continuous development of the global economy, the economic globalization and financial liberalization deepened, the capital flows and information dissemination between financial markets gradually enhanced. Both international financial market and sub-market are showing an increasingly significant linkage effect. When a market's price fluctuates under some shocks, other market asset prices may also be affected. Meanwhile, market participants will usually predict 
the trends of other market's price according to one market's price, resulting in expectation changes self-realization, which is so-called the market spillover effect (Hamao et al., 1990). Spillover effects include mean spillover effects and volatility spillover effects. The mean spillover effect usually refers to that yield of one market has influence on other markets, which can be positive or negative. For example, the decline in interest rates may lead to the rising in the stock market, which means the relationship between interest rate is negative. However, volatility spillover effects mean that the fluctuations of one market return (changes in variance of yield) have impact on other markets. And this effect can be large or small but no positive and negative differences. From the perspective of economic vision, volatility spillovers can be seen as the risk transfer between different markets.

Stock market, exchange market and money market are an important part of financial market. They can not only realize the optimization of resource distribution but also and diversify market risk. What's more, they are also the main place for government to implement monetary policy and macroeconomic regulation. In an open economic environment, stock price (asset price), exchange rates and interest rates are several important policy instruments for government to maintain national economic security and financial stability. By timely interventing interest rates, exchange rates and asset prices, the government can effectively mitigate the effects of external shocks on macroeconomic so that the entire financial system can run well. In the process of market-oriented reform of interest rate and exchange rate formation mechanism, Chinese stock market was subject to fluctuate greatly. Therefore, to make clear that the relationship and mechanism of the financial sub-market, we have attracted the academic, practical and financial authorities. Currently, deeply studying the synergistic effect between the financial markets in China not only helps to understand the interacted relationship between the financial market, but also has a certain reference significance for preventing the financial risk and the financial market reform and other aspects of policy formulation.

\section{Literature Review}

As to the stock market and the spillover effect between the foreign exchange market, foreign scholars have a more in-depth study. The performance of the linkage between the stock market and the foreign exchange market in different countries is variation. Morales (2008) [1] investigates the nature of volatility spillovers between stock returns and a number of exchange rates in six Latin American countries and one European economy in the 1998-2006 period. The results show that the volatility of stock returns affects the volatility of exchange rates; however, he does not find evidence of volatility transmission in the opposite direction. Zhao (2010) [2] empirically analyzes the dynamic relationship between Renminbi (RMB) real effective exchange rate and stock price with VAR and multivariate generalized autoregressive conditional heteroskedasticity (GARCH) models using monthly data from January 1991 to June 2009. The re- 
sults show that there is not a stable long-term equilibrium relationship between RMB real effective exchange rate and stock price. Jackman (2013) [3] incorporate the Castle and Hendry portmanteau test into an Exponential Generalized Autoregressive Conditional Hetroscedasticity in Mean (EGARCH-M) model to investigate nonlinearities in the reaction of daily foreign exchange activity to the interest rate differential between the US and Barbados-a small open economy which has been pegged to the US dollar for over 35 years. The results suggest that changes in the interest differential have a significant and nonlinear effect on the Barbadian foreign exchange market. The literature about the correlation study between interest rate and stock market, Jansen et al. (2010) [4] examine asymmetries in the impact of monetary policy surprises on stock returns between bull and bear markets in the period 1994 to 2005. They find that the impact of a surprise monetary policy in a bear market is large, negative, and statistically significant, and this holds across size decile portfolios. Ioannidis et al. (2008) [5] investigates the impact of monetary policy on stock returns in 13 OECD countries over the period 1972-2002. The results indicate that monetary policy shifts significantly affect stock returns, thereby supporting the notion of monetary policy transmission via the stock market. Our contribution with respect to previous work is threefold.

Upon the relationship between the money market and the foreign exchange market, the theoretical circles have developed a relatively consistent and mature theory. Hoffmann (2007) [6] empirically investigates Mundell's (1961) formalisation that in a small open economy flexible exchange rates act as a shock absorber. The role of a world real interest rate shock in driving output, trade imbalances and real exchange rate fluctuations under different exchange rate regimes is empirically investigated in a Panel VAR, which utilises economic theory for identification. By studying data from Canada, New Zealand and Australia, Zettelmeyer (2004) [7] found that when the central bank implemented a tight monetary policy, it could lead to a rise in the country's currency, which had a significant impact on the exchange rate.

In recent years, with the continuous progress of China's financial market reform, stock market, foreign exchange market and the linkage between the money market is gradually strengthening, the domestic academic draw more attention to this phenomenon. Xiao et al. (2011) [8] examine the characteristics of China's monetary demand from 1999 to 2010, they found that the volatility of exchange rate market could cause international capital flows and cause shocks in China's stock market in the short term. Yan et al. (2013) [9] examined the dynamic correlation between China's financial markets before, during and after the financial crisis. The result show that there is no long-term equilibrium relationship, but has a one-way spillover effect. Wu et al. (2014) [10] chose the monthly data from January 2002 to March 2014 to study the time-varying characteristics of the dynamic relationship between the stock market, exchange market and money market. The results show that the interaction between RMB exchange rate, short-term capital and stock price is time-varying. 
According to above literature, we conclude that domestic and foreign scholars use various empirical methods to study the stock market and exchange market, exchange market and money market and the linkage between money market and stock market in different countries, confirming that there is mean spillover effect or volatility spillover effect in various countries. But these studies focus mostly on two markets including stock market and exchange market, money market and exchange market, or stock market and bond market and so on. They can't comprehensively examine the dynamic relationship between financial markets. This paper is to integrate stock price, $\mathrm{RMB}$ exchange rate and interest rate into a system, and use the data to analyze the dynamic relationship between the three markets, which can help institutional investors and financial regulators fully understand the relationship. In addition, based on the existing research, this paper comprehensively analyzes the Chinese stock market, the foreign exchange market and the money market, which makes the conclusion more robust and reliable. As the stock index, exchange rate and money market interest rates are changing every day, this paper intends to use the ternary VAR-GARCH-BEKK model to analyze the daily data of three variables and further confirm whether there is a single or bi-directional effect.

\section{Methodology}

In the present study, we adopt a three-variable GARCH-BEKK model developed by Engle and Kroner to investigate volatility spillover between three markets. The advantage of the BEKK specification is that it does not impose any restriction on the correlation structure between the variables.

Usually, the AIC and SC information criteria can be used to choose the optimal lag length of GARCH process (i.e., the values of $\mathrm{p}$ and $\mathrm{q}$ ). However, in the study of T. Bollerslev, they found an interesting result. With small numbers of parameters, GARCH $(1,1)$ process is sufficient to model the variance dynamics of financial time series. So similar to the previous researches, we select one lag for the mean and variance equations.

Generally, the mean equation of a three-variable GARCH $(1,1)$ model can be defined by the following equations:

$$
\begin{aligned}
& r_{s r, t}=\alpha_{s t}+\sum_{i=1}^{n} \lambda_{s r i} r_{e r, t-i}+\sum_{i=1}^{n} \delta_{s r i} r_{i r, t-i}+\sum_{i=1}^{n} \varphi_{s r i} r_{s r, t-i}+\varepsilon_{s r, t} \\
& r_{e r, t}=\alpha_{e r}+\sum_{i=1}^{n} \lambda_{e r i} r_{e r, t-i}+\sum_{i=1}^{n} \delta_{e r i} r_{i r, t-i}+\sum_{i=1}^{n} \varphi_{e r i} r_{s r, t-i}+\varepsilon_{e r, t} \\
& r_{i r, t}=\alpha_{i r}+\sum_{i=1}^{n} \lambda_{i r i} r_{e r, t-i}+\sum_{i=1}^{n} \delta_{i r i} r_{i r, t-i}+\sum_{i=1}^{n} \varphi_{i r i} r_{s r, t-i}+\varepsilon_{i r, t}
\end{aligned}
$$

In the above three formulas, $n$ is the optimal lag order of the VAR model. $\varepsilon_{s r, t}, \varepsilon_{e r, t}, \varepsilon_{i r, t}$ are the residual term for the mean equation, respectively.

The variance equation of the volatility spillover effect is as follows:

$$
H_{t}=C^{\prime} C+B^{\prime} H_{t-1} B+A^{\prime} \varepsilon_{t-1} \varepsilon_{t-1}^{\prime} A
$$

where: 


$$
\begin{aligned}
& H_{t}=\left(\begin{array}{lll}
h_{11, t} & h_{12, t} & h_{13, t} \\
h_{21, t} & h_{22, t} & h_{23, t} \\
h_{31, t} & h_{32, t} & h_{33, t}
\end{array}\right), B_{t}=\left(\begin{array}{lll}
b_{11} & b_{12} & b_{13} \\
b_{21} & b_{22} & b_{23} \\
b_{31} & b_{32} & b_{33}
\end{array}\right) \\
& C=\left(\begin{array}{ccc}
c_{11} & 0 & 0 \\
c_{21} & c_{22} & 0 \\
c_{31} & c_{32} & c_{33}
\end{array}\right), A_{t}=\left(\begin{array}{lll}
a_{11} & a_{12} & a_{13} \\
a_{21} & a_{22} & a_{23} \\
a_{31} & a_{32} & a_{33}
\end{array}\right)
\end{aligned}
$$

$A, B$ are $3 \times 3$ order matrix, The elements in main diagonals of $A$ represent the ARCH effect between the various markets; The elements in main diagonal of $B$ represents the GARCH effect. $a_{i j}$ and $b_{i j}(i \neq j)$ reflect the ARCH and GARCH effect of market $i$ to market $j . H_{t}$ is the conditional covariance matrix.

The model is estimated by the maximum likelihood estimation method optimized by the BHHH algorithm to obtain the final estimate of the variance-covariance matrix with corresponding standard errors. The conditional log likelihood function $I(\theta)$ can be expressed as follows:

$$
l(\theta)=-T \log (2 \pi)-(1 / 2) \sum_{t=1}^{T}\left(\ln \left|H_{t}\right|\right)+\varepsilon_{t}^{\prime} H_{t} \varepsilon_{t}
$$

where $T$ is the number of observations and $\theta$ represents the vector of all unknown parameters.

\section{Empirical Study}

\subsection{Data Collecting and Processing}

The empirical data sets used in this study consist of daily CSI 300 index, 7-day interbank interest rate and the central parity of the US dollar against the yuan. All the data are collected from Wind Database ${ }^{1}$, and encompass the period from June 2005 to December 2016. After excluding the some data, we get 2666 sets of data. For the Shanghai and Shenzhen 300 Index and the exchange rate, respectively, calculate the market rate of return, the formula is as follows:

$$
R_{t}=\ln \left(P_{t} / P_{t-1}\right) \times 100 \%
$$

\subsection{Data Descriptive Statistical Analysis}

For the purpose of exploring the trend of data distribution and finding extreme data, descriptive statistical analysis should be done before these data was used. Therefore, it is necessary to take this analysis method in this paper.

As seen in Table 1, we can find the standard deviation and range of $R_{s t}$ are maximum, which indicates that during July 22, 2005 to July 11, 2016 stock market volatility is more intensive than the foreign exchange market and money market. The JB value from above table shows that under the $1 \%$ significance lev$\mathrm{el}$, the three yield series are uniformly disguised from the normal distribution. That the absolute values of the skewness are all greater than 0 and the kurtosis is greater than 3 indicates that the three sequences spikes are thick. From the

${ }^{1}$ Wind is the market leader in China's financial information services industry, similar to Bloomberg in USA. 
Table 1. Descriptive statistics.

\begin{tabular}{cccc}
\hline & $R_{\text {st }}$ & $R_{e t}$ & $R_{i t}$ \\
\hline Max & 8.93 & 1.84 & 12.25 \\
Min & -9.69 & -0.56 & 0.92 \\
Mean & 0.05 & -0.007 & 2.94 \\
Std & 1.89 & 0.12 & 1.25 \\
Skewness & -0.56 & 3.61 & 1.27 \\
Kurtosis & 6.11 & 61.31 & 6.56 \\
JB & $1212.68^{* * *}$ & $383,467.8^{* * *}$ & $2127.82^{* * *}$ \\
Q (10) & $37.12^{* * *}$ & $116.52^{* * *}$ & $15,881.45^{* * *}$ \\
Q2 (10) & $583.12^{* * *}$ & $963.99^{* *}$ & $10,571.71^{* * *}$ \\
\hline
\end{tabular}

Note: ${ }^{*}, * *, * *$ : showed a significance level of $10 \%, 5 \%$, and $1 \%$, respectively.

Ljung-Box Q statistic of the sequence itself, the three yield series have different degrees of autocorrelation, and the squared Ljung-Box Q statistic is significant, which indicates that the square of the yield series also has autocorrelation. All yield sequences have significant fluctuation clustering effect.

Figure 1 is the stock market rate of return sequence, the foreign exchange market and the money market rate of return sequence chart, which shows stock market volatility is the highest, and the three markets are significant fluctuation cluster effect.

In order to analyze time series data, stationary of the data is a prerequisite. However, most macroeconomic variables are known to be non-stationary. As such, a unit-root test was first conducted on three variables. To examine this, the Augmented Dicky-Fuller test was used. The results are shown in Table 1. We could find that the two tests on the unit-root show that all level variables were nonstationary time series. However, all difference variables dismissed the null hypothesis within a significance level of $1 \%$, making it stationary time series.

\subsection{Analysis of Mean Spillover Effect}

In order to analyze time series data, stationary of the data is a prerequisite. However, most macroeconomic variables are known to be non-stationary. As such, a unit-root test was first conducted on the level variables such as the stock price, interest rate, and won/dollar exchange in order to determine the stationary of the time series data. To examine this, the Augmented Dicky-Fuller test was used. The results are shown in Table 2.

\subsection{Analysis of Mean Spillover Effect Based on VAR Model}

According to Akai Information Criterion (AIC), Likelihood Ratio (LR) and Final Error (FPE), the optimal lag order of VAR model is 7. It can be seen that for the VAR model the mould of unit root is less than 1 so it can be considered robust.

As seen in Table 3, (1) the three series yield are significantly affected by their own lag. Among them, the stock market yield lag 4 and 6 have a significant impact on the current period. The foreign exchange market yields lag 1, 5 and 7 

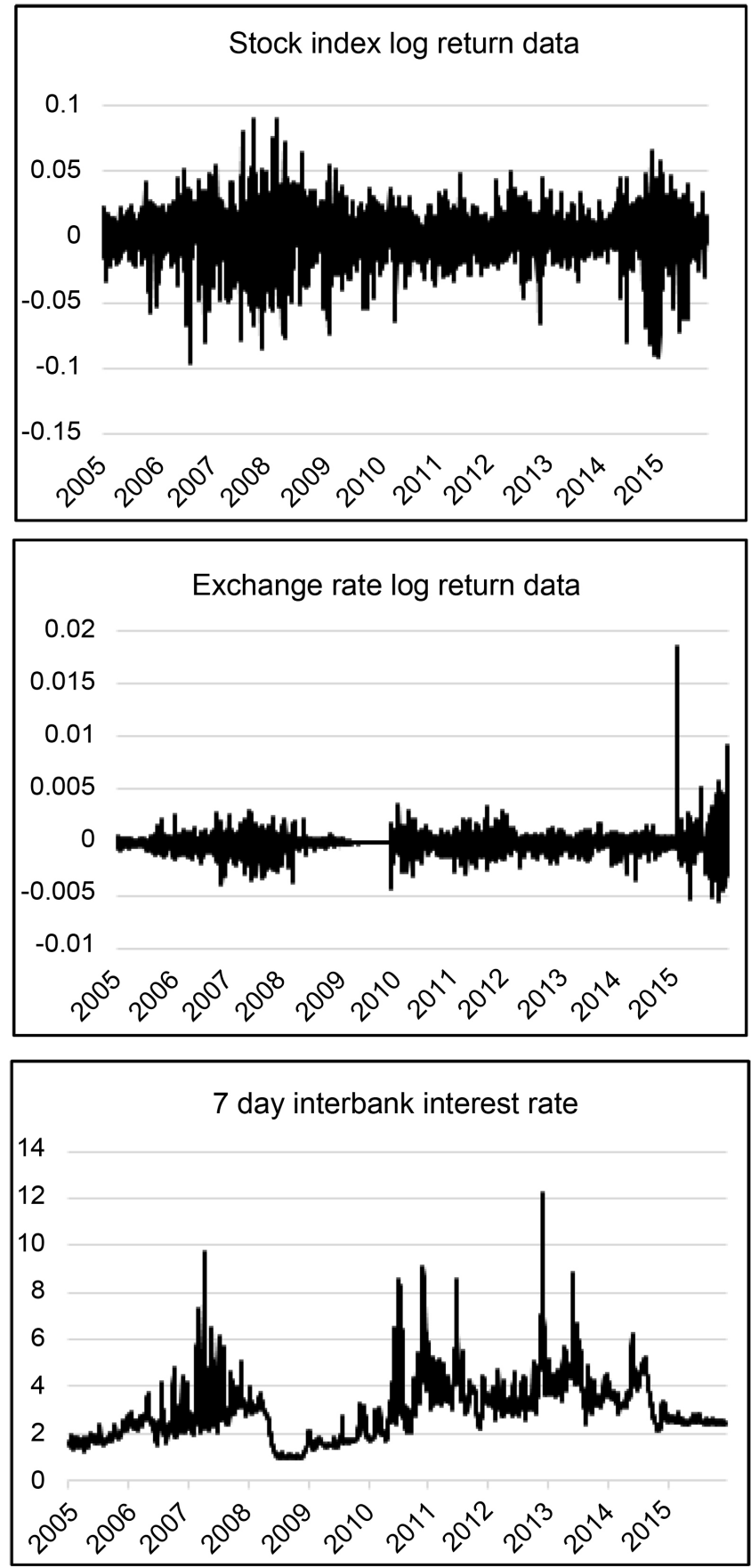

Figure 1. Three markets return July 22, 2005 to July 11, 2016.

Table 2. Unit root test of the variable.

\begin{tabular}{cccccc}
\hline Variables & $(\mathrm{c}, \mathrm{t}, \mathrm{p})$ & $\begin{array}{c}\mathrm{ADF} \\
\text { Statistics }\end{array}$ & $1 \%$ critical value & $5 \%$ critical value & $10 \%$ critical value \\
\hline$R_{s t}$ & $(\mathrm{c}, 0,0)$ & -50.06 & -3.44 & -2.86 & -2.57 \\
$R_{e t}$ & $(\mathrm{c}, 0,0)$ & -42.91 & -3.44 & -2.86 & -2.57 \\
$R_{i t}$ & $(\mathrm{c}, 0,0)$ & -3.82 & -3.44 & -2.86 & -2.57 \\
\hline
\end{tabular}

Note: $(\mathrm{c}, \mathrm{t}, \mathrm{p})$ represents the intercept term, the trend term and the lag order, respectively. 
Table 3. The estimated results of VAR model.

\begin{tabular}{|c|c|c|c|}
\hline & RHS & REX & IR7 \\
\hline RHS (-1) & $0.0317[1.6305]$ & $-0.0004[-0.3243]$ & $-0.0059[-1.4292]$ \\
\hline RHS (-2) & $-0.0286[-1.4720]$ & $0.0015[1.3976]$ & $0.0006[0.1442]$ \\
\hline RHS (-3) & $0.0191[0.9801]$ & $0.0007[0.6696]$ & $-0.0079 *[-1.9071]$ \\
\hline RHS (-4) & $0.0715^{\star \star \star}[3.6842]$ & $-0.0005[-0.4186]$ & $0.0002[0.0497]$ \\
\hline RHS $(-5)$ & $0.0041[0.2118]$ & $-0.0001[-0.1354]$ & $-0.0035[-0.8378]$ \\
\hline RHS (-6) & $-0.0620^{* * *}[-3.1939]$ & $0.0012[1.091]$ & $0.0006[0.1439]$ \\
\hline RHS $(-7)$ & $0.0268[1.3782]$ & $0.0006[0.51407]$ & $0.0016[0.3840]$ \\
\hline $\operatorname{REX}(-1)$ & 0.5193 [1.5059] & $0.1863^{\star * *}[9.5748]$ & $0.0108[0.1469]$ \\
\hline $\operatorname{REX}(-2)$ & $-0.2857[-0.8150]$ & $-0.0076[-0.3838]$ & $-0.0459[-0.6126]$ \\
\hline $\operatorname{REX}(-3)$ & $0.2703[0.7714]$ & $0.0101[0.5133]$ & $0.0289[0.3869]$ \\
\hline $\operatorname{REX}(-4)$ & $-0.1571[-0.4475]$ & $0.0158[0.7956]$ & $-0.0330 *[-1.9395]$ \\
\hline $\operatorname{REX}(-5)$ & $-0.2200[-0.6265]$ & $-0.0381^{\star}[-1.9228]$ & $-0.0178[-0.2376]$ \\
\hline $\operatorname{REX}(-6)$ & $0.0374[0.1066]$ & $-0.0089[-0.4532]$ & $0.0163[0.2176]$ \\
\hline $\operatorname{REX}(-7)$ & $-1.2753^{\star * \star}[-3.6882]$ & $0.0682^{\star * \star}[3.4958]$ & $-0.0893[-1.2074]$ \\
\hline IR7 $(-1)$ & $-0.0824[-0.9072]$ & $-0.0007[-0.1332]$ & $1.0063^{\star * \star}[51.7755]$ \\
\hline IR7 $(-2)$ & $-0.1176[-0.9161]$ & $0.0066[0.9066]$ & $-0.1179^{* * \star}[-4.2942]$ \\
\hline IR7 $(-3)$ & $0.1953^{*}[1.8272]$ & $-0.0113[-1.5449]$ & $0.0063[0.23014]$ \\
\hline IR7 $(-4)$ & $0.0074[0.0575]$ & $-0.0004[-0.0600]$ & $0.0365[1.3262]$ \\
\hline IR7 $(-5)$ & $-0.0966[-0.7501]$ & $0.0177^{\star * *}[2.4413]$ & $-0.0606^{\star \star}[-2.2003]$ \\
\hline $\operatorname{IR7}(-6)$ & $0.1899[1.4773]$ & $-0.0239^{* * *}[-3.3019]$ & $0.1511^{\star * \star}[5.4958]$ \\
\hline IR7 $(-7)$ & $-0.1343[-1.4763]$ & $0.0103^{* *}[2.0135]$ & $-0.0727^{\star * *}[-3.7354]$ \\
\hline Constant & $0.1490[1.4913]$ & $-0.0009[-0.1591]$ & $0.1498^{* * *}[7.0121]$ \\
\hline
\end{tabular}

Note: ${ }^{*}{ }^{* *},{ }^{* * *}$ : showed a significance level of $10 \%, 5 \%$, and $1 \%$, respectively.

have a significant impact on the current period, the lag 1,2, 5, 6 and 7 period of the money market interest rate have significant effects on the current period, indicating that there are different degree of autocorrelation in all market yields. From the point of view of the significance level of the variables, for the stock market equation, the lag 7 of exchange rate is significant at $1 \%$ level, and the lag 3 of money market yield is significant at the level of $10 \%$. For the exchange rate equation, the lag 5, 6 and 7 of money market rate were significant at $1 \%, 1 \%$ and $5 \%$ respectively. For the money market interest rate equation, the lagged 3 stock return and the lagged 4 foreign exchange market at $10 \%$ level

As seen in Table 4 , under the $1 \%$ significant level, null hypothesis $H_{0}: \theta_{1,1}=\theta_{1,2}=\theta_{1,3}=\theta_{1,4}=\theta_{1,5}=\theta_{1,6}=\theta_{1,7}=0$ and $H_{0}: \kappa_{1,1}=\kappa_{1,2}=\kappa_{1,3}=\kappa_{1,4}=\kappa_{1,5}=\kappa_{1,6}=\kappa_{1,7}=0$ were refused, which shows there was mean spillover effect from exchange return and money market yield to stock market yield. On the other hand, null hypothesis $H_{0}: \theta_{2,1}=\theta_{2,2}=\theta_{2,3}=\theta_{2,4}=\theta_{2,5}=\theta_{2,6}=\theta_{2,7}=0$ was accepted, which shows there was no mean spillover effect from stock market return to exchange rate yield. Under the 5\% significant level, null hypothesis 
Table 4. Mean spillover effect test.

\begin{tabular}{|c|c|c|}
\hline $\begin{array}{l}\text { Analysis of Mean Spillover } \\
\text { Effect of Equity Returns }\end{array}$ & $\begin{array}{l}\text { Exchange rate yield } \\
\text { equation mean } \\
\text { spillover effect test }\end{array}$ & $\begin{array}{l}\text { Monetary Market Interest } \\
\text { Rate Equations Mean } \\
\text { Spillover Effect Test }\end{array}$ \\
\hline $\begin{array}{l}\text { The Mean Spillover Effect of } \\
\text { Exchange Market to the Stock }\end{array}$ & $\begin{array}{l}\text { The Mean Spillover Effect } \\
\text { of Stock Market to Foreign }\end{array}$ & $\begin{array}{l}\text { The Mean Spillover Effect of } \\
\text { Stock Market to Money }\end{array}$ \\
\hline Market & Exchange Market & Market \\
\hline $\begin{array}{c}H_{0}: \theta_{1,1}=\theta_{1,2}=\theta_{1,3}=\theta_{1,4} \\
=\theta_{1,5}=\theta_{1,6}=\theta_{1,7}=0 \\
\mathrm{~F}=2.46^{\star * \star}\end{array}$ & $\begin{array}{c}H_{0}: \theta_{2,1}=\theta_{2,2}=\theta_{2,3}=\theta_{2,4} \\
=\theta_{2,5}=\theta_{2,6}=\theta_{2,7}=0 \\
\mathrm{~F}=0.699\end{array}$ & $\begin{array}{c}H_{0}: \theta_{3,1}=\theta_{3,2}=\theta_{3,3}=\theta_{3,4} \\
=\theta_{3,5}=\theta_{3,6}=\theta_{3,7}=0 \\
\mathrm{~F}=1.74^{\star}\end{array}$ \\
\hline $\begin{array}{c}\text { The Mean Spillover Effect of } \\
\text { Money Market To Stock } \\
\text { Market }\end{array}$ & $\begin{array}{c}\text { The Mean Spillover Effect } \\
\text { of Money Market To } \\
\text { Exchange Market }\end{array}$ & $\begin{array}{c}\text { The Mean Spillover Effect of } \\
\text { Money Market To Exchange } \\
\text { Market }\end{array}$ \\
\hline $\begin{array}{c}H_{0}: \kappa_{1,1}=\kappa_{1,2}=\kappa_{1,3}=\kappa_{1,4} \\
=\kappa_{1,5}=\kappa_{1,6}=\kappa_{1,7}=0 \\
\mathrm{~F}=4.25^{\star \star *}\end{array}$ & $\begin{array}{c}H_{0}: \kappa_{2,1}=\kappa_{2,2}=\kappa_{2,3}=\kappa_{2,4} \\
=\kappa_{2,5}=\kappa_{2,6}=\kappa_{2,7}=0 \\
\mathrm{~F}=2.15^{* *}\end{array}$ & $\begin{array}{c}H_{0}: \kappa_{3,1}=\kappa_{3,2}=\kappa_{3,3}=\kappa_{3,4} \\
=\kappa_{3,5}=\kappa_{3,6}=\kappa_{3,7}=0 \\
\mathrm{~F}=1.85^{\star *}\end{array}$ \\
\hline
\end{tabular}

Note: ${ }^{* * *},{ }^{* * *}$ : showed a significance level of $10 \%, 5 \%$, and $1 \%$, respectively.

$H_{0}: \kappa_{2,1}=\kappa_{2,2}=\kappa_{2,3}=\kappa_{2,4}=\kappa_{2,5}=\kappa_{2,6}=\kappa_{2,7}=0$ was refused, which shows there was mean spillover effect from money market return to exchange rate yield. Under the $10 \%$ and $5 \%$ significant level, null hypothesis

$H_{0}: \theta_{3,1}=\theta_{3,2}=\theta_{3,3}=\theta_{3,4}=\theta_{3,5}=\theta_{3,6}=\theta_{3,7}=0$ and

$H_{0}: \kappa_{3,1}=\kappa_{3,2}=\kappa_{3,3}=\kappa_{3,4}=\kappa_{3,5}=\kappa_{3,6}=\kappa_{3,7}=0$ was refused respectively, which indicate that there was mean spillover effect from exchange return and stock market yield to money market yield.

\subsection{Analysis on Volatility Spillover Effect}

In this paper, we use the maximum likelihood estimation to estimate the parameters of the GARCH-BEKK $(1,1)$ model. Given that the log-likelihood function is nonlinear, we use the BFGS algorithm and Wald test. Winrats 8.0 was chosen.

As shown at Table 5 , under the $1 \%$ significant level, the coefficient of $A(1,1)$, A $(2,2)$, and $\mathrm{A}(3,3)$ in $\mathrm{ARCH}$ matrix was significant, which reflects the three data series shows ARCH effect. Under the $1 \%$ significant level, the coefficient of B $(1,1), B(2,2)$, and B $(3,3)$ in GARCH matrix was significant, which reflects the three data series shows GARCH effect.

As shown in Table 6, we can know that there was only two-way volatility spillover effect between stock market and money market, and one-way volatility spillover effect between other market. Specifically, under the $1 \%$ significant level, there was two-way volatility spillover effect between stock market and exchange market.

\section{Conclusions and Policy Implications}

Based on the high frequency daily data of China's stock market, foreign exchange market and money market interest rate from July 2005 to December 2016, this paper chooses VAR (7)-GARCH (1,1)-BEKK model to study the mean spillover effect and volatility spillover effect between the three markets. Results 
Table 5. Estimated Results of GARCH-BEKK $(1,1)$.

\begin{tabular}{ccccc}
\hline Variables & Coefficient & Std & T Statistic & P value \\
\hline C $(1,1)$ & $0.2939^{* * *}$ & 0.0303 & 9.7171 & 0.0000 \\
C $(2,1)$ & $-0.0086^{* * *}$ & 0.0011 & -8.1369 & 0.0000 \\
C $(2,2)$ & 0.0010 & 0.0011 & 0.9487 & 0.3428 \\
C $(3,1)$ & -0.0052 & 0.0053 & -0.9901 & 0.3221 \\
C $(3,2)$ & $0.0398^{* * *}$ & 0.0037 & 10.7378 & 0.0000 \\
C $(3,3)$ & 0.0000 & -0.0472 & 0.0000 & 1.0000 \\
A $(1,1)$ & $0.2931^{* * *}$ & 0.0146 & 20.0349 & 0.0000 \\
A $(1,2)$ & $-0.0044^{* * *}$ & 0.0006 & -6.9576 & 0.0000 \\
A $(1,3)$ & $-0.0037^{* *}$ & 0.0016 & -2.3031 & 0.0213 \\
A $(2,1)$ & $0.9476^{* * *}$ & 0.2149 & 4.4102 & 0.0000 \\
A $(2,2)$ & $0.2261^{* * *}$ & 0.0117 & 19.3120 & 0.0000 \\
A $(2,3)$ & 0.0029 & 0.0168 & 0.1724 & 0.8631 \\
A $(3,1)$ & 0.0276 & 0.0701 & 0.3931 & 0.6942 \\
A $(3,2)$ & $0.0082^{* *}$ & 0.0032 & 2.5416 & 0.0110 \\
A $(3,3)$ & $0.5619^{* * *}$ & 0.0265 & 21.1826 & 0.0000 \\
B $(1,1)$ & $0.9439^{* * *}$ & 0.0050 & 188.2448 & 0.0000 \\
B $(1,2)$ & $0.0025^{* * *}$ & 0.0002 & 15.2582 & 0.0000 \\
B $(1,3)$ & $0.0013^{* *}$ & 0.0005 & 2.5293 & 0.0114 \\
B $(2,1)$ & $-0.4804^{* * *}$ & 0.0979 & -4.9058 & 0.0000 \\
B $(2,2)$ & $0.9704^{* * *}$ & 0.0033 & 293.9139 & 0.0000 \\
B $(2,3)$ & -0.0047 & 0.0082 & -0.5698 & 0.5688 \\
B $(3,1)$ & -0.0147 & 0.0254 & -0.5764 & 0.5644 \\
B $(3,2)$ & $-0.0043^{* * *}$ & 0.0012 & -3.6130 & 0.0003 \\
B $(3,3)$ & $0.8693^{* * *}$ & 0.0104 & 83.8755 & 0.0000 \\
\hline
\end{tabular}

Note: *, **, ***: showed a significance level of $10 \%, 5 \%$, and $1 \%$, respectively.

of analyses conducted in this study show that firstly, between currency market and stock market there is only unidirectional mean spillover effect from currency market to stock market; secondly, however, there exists asymmetrical bidirectional mean spillover effect both between stock market and money market and currency market and money market, which exhibits time-varying variance and volatility persistence; thirdly, there exists bidirectional volatility spillover effect between currency market and money market, however there is only unidirectional volatility spillover effect from stock market to money market, which is demonstrated from money market to currency market.

Thus, the results of this study can provide us with the following policy implications for a more stable and efficient management of financial asset prices.

First, the reason for the volatility spillover of financial market is that the coordinated movement happens in the price or volatility within the financial market. Owing to China's financial market with linkage characteristics, it is necessary to construct a coordinated interaction mechanism between different markets to 
Table 6. The test result of volatility spillover.

\begin{tabular}{|c|c|c|c|}
\hline Test item & $\begin{array}{l}\text { Hypotheses } \\
\text { Testing } 1\end{array}$ & $\begin{array}{l}\text { Hypotheses } \\
\text { Testing } 2\end{array}$ & $\begin{array}{l}\text { Hypotheses } \\
\text { Testing } 3\end{array}$ \\
\hline $\begin{array}{c}\text { Stock and } \\
\text { exchange } \\
\text { market }\end{array}$ & $\begin{array}{c}\text { no one-way volatility } \\
\text { spillover from stock } \\
\text { market to exchange } \\
\text { market } \\
H_{0}: a_{12}=b_{12}=0 \\
\text { Wald }=235.24^{\star * \star}\end{array}$ & $\begin{array}{c}\text { no one-way } \\
\text { volatility spillover } \\
\text { from exchange } \\
\text { market to stock } \\
\text { market } \\
H_{0}: a_{21}=b_{21}=0 \\
\text { Wald }=26.20^{* * *}\end{array}$ & $\begin{array}{c}\text { no volatility spillover } \\
\text { between stock market } \\
\text { and exchange market } \\
H_{0}: a_{12}=b_{12}=a_{21}=b_{21}=0 \\
\text { Wald }=251.15^{\star * *}\end{array}$ \\
\hline $\begin{array}{c}\text { Stock and } \\
\text { money market }\end{array}$ & $\begin{array}{c}\text { no one-way volatility } \\
\text { spillover from stock } \\
\text { market to money } \\
\text { market } \\
H_{0}: a_{13}=b_{13}=0 \\
\text { Wald }=8.35^{\star *}\end{array}$ & $\begin{array}{c}\text { no one-way } \\
\text { volatility spillover } \\
\text { from money market } \\
\text { to stock market } \\
H_{0}: a_{31}=b_{31}=0 \\
\text { Wald }=0.37\end{array}$ & $\begin{array}{c}\text { no volatility spillover } \\
\text { between stock market } \\
\text { and money market } \\
H_{0}: a_{13}=b_{13}=a_{31}=b_{31}=0 \\
\text { Wald }=8.49^{* *}\end{array}$ \\
\hline $\begin{array}{l}\text { Exchange and } \\
\text { money market }\end{array}$ & $\begin{array}{l}\text { no one-way volatility } \\
\text { spillover from } \\
\text { exchange market to } \\
\text { money market } \\
H_{0}: a_{23}=b_{23}=0 \\
\text { Wald }=0.34\end{array}$ & $\begin{array}{c}\text { no one-way } \\
\text { volatility spillover } \\
\text { from money market } \\
\text { to exchange market } \\
H_{0}: a_{32}=b_{32}=0 \\
\text { Wald }=14.19^{\star * *}\end{array}$ & $\begin{array}{c}\text { no volatility spillover } \\
\text { between exchange market } \\
\text { and money market } \\
H_{0}: a_{23}=b_{23}=a_{32}=b_{32}=0 \\
\text { Wald }=14.36^{* * *}\end{array}$ \\
\hline
\end{tabular}

Note: ${ }^{*}, * * * * *$ showed a significance level of $10 \%, 5 \%$, and $1 \%$, respectively.

mitigate the risk in markets.

Second, between China's stock market, exchange market and money market interest rates, there exits significant market conductivity, and the spillover effect is obvious. Thus, there need to take more reasonable and effective regulation steps and pay close attention to market volatility and mutual influence so that government can prevent financial risks spreading.

\section{Further Study}

Although this paper analyzes the spillover effect among stock, money and foreign exchange market, it is still not perfect. Broadly speaking, in addition to the three main markets discussed in the paper, financial markets also include the gold market, which could lead to fluctuation stock, money and foreign exchange market. For the deeply research, gold market should be considered.

What's more, the robustness test examines the robustness of the empirical method and the explanatory. In other words, when changing certain parameters, the empirical results still maintain a consistent and stable. In order to ensure the robustness of empirical results, robustness test should be taken for further study.

\section{References}

[1] Morales, L.D. (2008) Volatility Spillovers between Equity and Currency Markets: Evidence from Major Latin American Countries. Latin American Journal of Economics, 45, 185-215. 
[2] Zhao, H. (2010) Dynamic Relationship between Exchange Rate and Stock Price: Evidence from China. Research in International Business and Finance, 24, 103-112. https://doi.org/10.1016/j.ribaf.2009.09.001

[3] Jackman, M., Craigwell, R. and Doyle-Lowe, M. (2013) Nonlinearity in the Reaction of the Foreign Exchange Market to Interest Rate Differentials: Evidence from a Small Open Economy with a Long-Term Peg. Applied Financial Economics, 23, 287-296. https://doi.org/10.1080/09603107.2012.718063

[4] Dennis, J. and Li, T.C. (2010) Monetary Policy and Stock Returns: Financing Constraints and Asymmetries in Bull and Bear Markets. Journal of Empirical Finance, 5, 981-990.

[5] Christos, I. and Kontonikas, A. (2008) The Impact of Monetary Policy on Stock Prices. Journal of Policy Modeling, 30, 33-53.

https://doi.org/10.1016/j.jpolmod.2007.06.015

[6] Mathias, H. (2007) Fixed versus Flexible Exchange Rates: Evidence from Developing Countries. Economica, 74, 425-449. https://doi.org/10.1111/j.1468-0335.2006.00564.x

[7] Jeromin, Z. (2004) The Impact of Monetary Policy on the Exchange Rate: Evidence from Three Small Open Economies. Journal of Monetary Economics, 51, 635-652. https://doi.org/10.1016/j.jmoneco.2003.06.004

[8] Xiao, W.G. and Yuan, W. (2011) Stock Market, RMB Exchange Rate and China's Money Demand. Finance Research, 4, 52-64.

[9] Yan, S. and Li, L.-W. (2013) Study on Dynamic Correlation between Chinese Stock Market and Foreign Exchange Market. Macroeconomic Research, 3, 32-40.

[10] Wu, L.-H. and Fu, G.-M. (2014) Effects of RMB Exchange Rate, Short-Term Capital and Stock Price. Economic Research, 11, 72-86.

\section{Submit or recommend next manuscript to SCIRP and we will provide best} service for you:

Accepting pre-submission inquiries through Email, Facebook, LinkedIn, Twitter, etc. A wide selection of journals (inclusive of 9 subjects, more than 200 journals)

Providing 24-hour high-quality service

User-friendly online submission system

Fair and swift peer-review system

Efficient typesetting and proofreading procedure

Display of the result of downloads and visits, as well as the number of cited articles

Maximum dissemination of your research work

Submit your manuscript at: http://papersubmission.scirp.org/

Or contact me@scirp.org 